\title{
Physicochemical characterisation and in vitro evaluation of modified release matrix tablets: The role of different grades of hydroxypropylmethyl cellulose
}

\author{
Vesna Petrovska Jovanovska ${ }^{1 *}$, Ljupco Pejov $^{2}$, Aleksandra Petrovska ${ }^{1}$, \\ Sonja Ugarkovic ${ }^{1}$, Maja Simonoska Crcarevska ${ }^{3}$, Marina Galeva ${ }^{3}$, \\ Marija Glavas Dodov ${ }^{3}$ \\ ${ }^{I}$ Research \& Development, Alkaloid AD-Skopje, Blv. Aleksandar Makedonski 12, 1000 Skopje, Macedonia \\ ${ }^{2}$ Institute of Chemistry, Faculty of Natural Sciences and Mathematics, \\ Ss. Cyril and Methodius University, POBox 162, 1001 Skopje, Macedonia \\ ${ }^{3}$ Institute of Pharmaceutical Technology, Center for Pharmaceutical Nanotechnology,Faculty of Pharmacy, \\ Ss. Cyril and Methodius University, Majka Tereza 47, 1000 Skopje, Macedonia
}

\begin{abstract}
The purpose of this work was to formulate prolonged release matrix tablets with water soluble opioid drug (API) using different types of hydroxypropylmethyl cellulose (Methocel) as controlled release polymers. Methocel K100M was incorporated as intra-granular polymer (sample 1) along with Methocel K4M (sample 2) or Methocel K15M (sample 3) as extra-granular polymers. The final blends and tablets prepared by wet granulation process were fully characterized.

Results showed that the polymer used extra-granularly significantly affects the tablet properties. By incorporation of Methocel extra granularly (samples 2 and 3), the hardness and tensile strength of the tablets increased and the total tablet porosity decreased. Sample 1, containing only Methocel K100M (intra granularly) has the lowest index of swelling and the fastest release of API probably due to the cross-linking of the polymer chains during the process of wet granulation. Also, the type of Methocel used extra-granularly (with different viscosity grade) was found to significantly affect the swelling ratio of the designed matrix systems and the drug release behavior. Sample 2 containing Methocel K4M extra-granularly has a lower index of swelling and faster release of API compared to sample 3. Considering the release mechanism, release data showed best fitting to the heuristic model proposed by Korsmeyer-Peppas. Two additional approaches were used for mathematical modeling of the release data in order to make them directly applicable for our experimental results.
\end{abstract}

Keywords: matrix tablet, water soluble opioid drug, prolonged release, HPMC (Methocel)

\section{Introduction}

The recognition and treatment of pain have become a major focus of health-care professionals. Oral opioids have become the drugs of choice for the treatment of moderate-to-severe chronic pain because of flexibility, convenience and ability to maintain relatively steady blood concentrations. For chronic pain management, a continuous, around-the-clock therapy is needed which provides the most effective analgesia and results in the fewest undesirable side effects. However, frequent

\footnotetext{
*vesna2p@yahoo.com
} 
administration, especially for agents with a short elimination half-life was recognized as inconvenient for the patients with chronic pain (Smith, 2012). These problems could be overcome by using oral modifiedrelease products with prolonged drug release as an efficient technological strategy for management of moderate-to-severe chronic pain.

From the industrial point of view, matrix systems are one of the most exploited oral prolonged release dosage forms because they are appropriate for low- and high-dose drug molecules with a wide range of physicochemical properties, they are cost-effective and generally easier to scale-up and manufacture compared with the other systems. In addition, these types of dosage forms are usually manufactured using conventional processing technology (Nokhodchi et al., 2012).

Quality by Design (QbD) methodology has become an essential requirement in the pharmaceutical industry (Charro et al., 2012). According to QbD, the quality of drug products should not be tested post hoc, but should be designed and built into the product (Yu et al., 2014). The most important aspects of the pharmaceutical development are the determination of the quality target product profile (QTPP) and identification of critical quality attributes (CQA) that affect the product quality, safety and efficacy.

For the design of new matrix drug product with prolonged release properties using $\mathrm{QbD}$ approach, a variety of polymers with different physicochemical characteristics could be used in order to modulate the drug release behavior. Therefore, during the one-factor-at-time experiments it is highly desirable to determine the critical material attributes (CMAs) of the selected functional excipient/s (controlled release polymer/s) and to know exactly the transport mechanisms involved in drug release process, as well as to be able to predict quantitatively the resulting drug release kinetics as the product most important CQA (Sauri et al., 2014).

The aim of this study was to formulate prolonged release matrix tablets with model opioid drug (API) by wet granulation process using different types of hydroxypropylmethyl cellulose (Methocel). The process settings were kept constant; hence, the focus was only on the variability of the polymers used and their properties. This research aims at examining and understanding the effects of the variability of raw material properties on the CQA - the in vitro release profile of the API and to correlate the CMA - type of the polymer used, which will affect the release behavior of the API.

\section{Material and methods}

\section{Materials}

Water-soluble compound (API) was used as a model drug (solubility $10.2 \mathrm{mg} / \mathrm{mL}, \mathrm{pK} 10.26$ and 9.12, Mw $473.49 \mathrm{~g} / \mathrm{mol}$, BCS Class III). The excipients used were:
Methocel K100M (Colorcon, EU), Methocel K15M (Colorcon, EU), Methocel K4M (Colorcon, EU), Kollidon K90 (BASF, Germany), Avicel PH 112 (FMC Biopolymer, USA) and magnesium stearate (Mg stearate) (Carsco GE, Italy). All the other chemicals used were of analytical grade.

\section{Methods}

During the preliminary studies, one factor at a time variation experiments were performed with a rationale for determination of key formulation (polymer type and concentration, type of granulating fluid: water or alcohol) and process (granulation method, compression force for tableting) factors influencing the properties of tablets and in vitro release of incorporated API (Petrovska et al., 2016). Optimized parameters were further used for formulation modification.

\section{Wet granulation technique and tablet manufacturing.}

The API was pre-blended with the intra-granular excipients (Avicel PH 112 and Methocel K100M) using laboratory mixer granulator (Diosna, Germany). Afterwards, Kollidon K90 (3\% sol. in alcohol 99\%, v/v) was added as a granulating fluid, the wet mass was passed through \#6 mesh and the granules were subsequently oven dried (MOV-212S; Panasonic, Japan). The granules were then passed through \#230 mesh and blended with lubricant (sample 1) or blended with extra-granular excipient (Methocel K4M - sample 2 or Methocel K15M sample 3) and lubricant to produce the final blend. The final blends were subsequently compacted into round 7.0 mm tablets using a 4-station rotary compression machine with compression force of 10.5-11.5 kN (Korsch XL 100, Germany). The composition of the prepared tablets (samples 1-3) is presented in Table 1.

Table 1. Composition of different tablet formulations

\begin{tabular}{|c|c|c|c|}
\hline Raw materials (\%) & Sample 1 & Sample 2 & Sample 3 \\
\hline API & 11.34 & 11.34 & 11.34 \\
\hline Methocel K100M & 43.56 & 21.78 & 21.78 \\
\hline Methocel K15M & l & l & 21.78 \\
\hline Methocel K4M & I & 21.78 & l \\
\hline Kollidon K90 & 3.00 & 3.00 & 3.00 \\
\hline Avicel PH 112 & 40.56 & 40.56 & 40.56 \\
\hline Mg Stearate & 1.50 & 1.50 & 1.50 \\
\hline Total (\%) & 100 & 100 & 100 \\
\hline
\end{tabular}




\section{Differential Scanning Calorimetry (DSC).}

DSC measurements of mixtures corresponding to prepared tablet formulations: a) mix of API, Methocel K100M, Avicel PH 112 and Kollidon K90 (intragranularly); b. mix of API, Methocel K100M, Avicel PH 112 and Kollidon K90 (intra-granularly) and Methocel K4M (extra-granularly) and c) mix of API, Methocel K100M, Avicel PH 112 and Kollidon K90 (intragranularly) and Methocel K15M (extra-granularly), were carried out using Netzsch DSC 204 F1 (Phoenix Instrument, Germany) in a pierced aluminium pans (2-3 $\mathrm{mg}$ of sample), under dynamic nitrogen atmosphere (30 $\mathrm{mL} / \mathrm{min}$ ). Heating-cooling cycles were applied for the mixtures: first, heating from room temperature to $180{ }^{\circ} \mathrm{C}$ with cooling from 180 to $0{ }^{\circ} \mathrm{C}$ and second, heating from 0 $-250{ }^{\circ} \mathrm{C}$ at heating/cooling rate of $20^{\circ} \mathrm{C} / \mathrm{min}$.

\section{Characterization of the final blends.}

Bulk and tapped densities, Carr-compressibility index, Hausner ratio and angle of repose of the prepared blends were determined using adequate Pharmacopoeia methods (Ph. Eur. 8.7).

Porosity of the final blends was determined by using formula:

$$
\text { Porosity }(\%)=[(V b-V t) / V b] \times 100
$$

where $\mathrm{Vb}$ is the bulk volume and $\mathrm{Vt}$ is the true volume (measured with helium gas displacement pycnometer (AccuPyc 1330; Micromeritics, Bedfordsire, UK)).

\section{Physical characterization of the prepared tablets.}

1) Weight variation. Ten tablets were used to study the weight variation using electronic balance (Sartorius Secura 224-1CU, Germany). 2) Tablet diameter, thickness and hardness. The diameter, thickness and tablet hardness was determined for ten tablets using ErwekaTablet Hardness Tester Type TBH 425 TD (Erweka GmbH, Germany). 3) Tensile strength (TS). From the obtained data of hardness, thickness and diameter of the tablets ( $n$ $=10$ ), the TS was calculated according to the equation (Franc et al., 2017):

$$
T S=2 F / \pi d t
$$

where $F$ is hardness of the tablet $(\mathrm{N}) ; d$ is the tablet diameter (mm) and $t$ is the tablet thickness (mm). 4).

\section{Porosity of tablets.}

Tablet porosity can affect the hardness, disintegration and dissolution of tablets and so understanding tablet porosity could be used to monitor the tabulating process. The geometric total tablet porosity $\left(\varepsilon_{\text {tot,geo }}\right)$ was calculated as one minus the ratio between the effective density of the tablet $\left(\rho_{\text {eff }}\right)$ and the apparent particle density of powder $\left(\rho_{\text {app }}\right)$ according to the equation:

$$
\varepsilon_{\text {tot,geo }}=1-\rho_{\text {eff }} / \rho_{\text {app }} * 100
$$

The $\rho_{\text {eff }}$ was in turn calculated as:

$$
\rho_{\text {eff }}=4 \times \mathrm{m} / \pi \mathrm{d}^{2} \mathrm{~h}
$$

where $m$ is the tablet weight, $d$ the tablet diameter and $h$ the tablet height $(n=10)$.

\section{Dynamic swelling (Swelling ratio index).}

For swelling kinetics, a gravimetric measurement was performed using 6 tablets from each batch sample (Saurí et al., 2014). The tablets were separately weighed (Wo) and placed in $900 \mathrm{~mL}$ phosphate buffer $\mathrm{pH} 6.8$ at $37^{\circ} \mathrm{C}$ and $50 \mathrm{rpm}$. At the determined time intervals (after 2, 4 and 6 hours), tablets were taken out from the medium and swabbed from excess water using filter paper, and then weighted $(W t)$. The swelling ratio index $(S R \%)$ was calculated using the following equation:

$$
S R(\%)=W t-W 0 / W t * 100 .
$$

In vitro drug release studies.

The dissolution testing was performed on six tablets from each batch using USP apparatus I (basket) in 900 $\mathrm{mL}$ of dissolution media (phosphate buffer $\mathrm{pH}$ 6.8) (VarianVankel 7025, Dissolution Instrument) at $37 \pm 0.5$ ${ }^{\circ} \mathrm{C}$ and $100 \mathrm{rpm}$ (The U.S. Pharmacopeia, 2011). At predetermined time intervals (after 2, 4, 6 and 10 hours), $5 \mathrm{~mL}$ samples were withdrawn with replacement. The collected samples were filtered through the $0.45 \mu \mathrm{m}$ filters and quantity of released API was determined by HPLC method (British Pharmacopeia, 2016).

The rate and mechanism of drug release from prepared prolonged release tablets were analyzed by fitting the dissolution data into commonly used kinetic equations (DDSolver 1.0 - Microsoft Excel menu-driven add-in program). Also, obtained results were evaluated using two additional approaches. The first one has been elaborated in the works of Aguzzi et al. (2013), while the second one is our slight modification of the Avrami's model, in order to make it directly applicable to our data.

Within the first approach, the process of adsorption of an adsorbable solute $\left(\mathrm{A}_{\mathrm{dis}}\right)$ onto solid-phase or macromolecular sorbent $\left(\mathrm{S}_{\mathrm{s}}\right)$ forming $\mathrm{S}-\mathrm{A}_{\mathrm{s}}$ adsorbate is kinetically modeled by a reversible generalized adsorption-desorption process of the form:

$$
\mathrm{S}_{\mathrm{s}}+\mathrm{A}_{\mathrm{dis}} \longleftrightarrow \mathrm{S}-\mathrm{A}_{\mathrm{s}}
$$

The kinetic equation governing the adsorptiondesorption process is:

$$
-\frac{\mathrm{d} C}{\mathrm{~d} t}=k_{\mathrm{a}} C^{n}(1-\theta)-k_{\mathrm{d}} \theta
$$


with $\theta$ actually being the fraction of the surface-active sites occupied by the sorbate, given by:

$$
\theta=\frac{C_{0}-C}{C_{0}-C_{\mathrm{e}}}
$$

In last equation (3), $C_{0}$ and $C_{\mathrm{e}}$ are the initial and equilibrium concentrations of the API. In the context of the present study we were actually interested in the release of API from prepared formulation samples. We therefore consider the kinetic equation for the release process, which is in a sense "inverse" to the one governing the adsorption process, i.e.:

$$
\frac{\mathrm{d} C}{\mathrm{~d} t}=-k_{\mathrm{a}} C^{n}(1-\theta)+k_{\mathrm{d}} \theta
$$

If the API adsorbed onto a carrier (or embedded into a carrier/formulation) is introduced into a solution, then the first term on the right-hand side of (4) becomes zero. Redefining for this case the parameter $\theta$ as:

$$
\theta=\frac{C_{e}-C}{C_{\mathrm{e}}}
$$

one actually has to solve the kinetic equation of the form:

$$
\frac{\mathrm{d} C}{\mathrm{~d} t}=k_{\mathrm{d}} \theta
$$

in which $\theta$ is defined by (5). Solving equation (6) with initial condition $C(t=0)=0$ leads to the following law governing the time-evolution of $C$, i.e. the dynamics of the release process:

$$
C(t)=C_{\mathrm{e}}\left[1-\exp \left(-\frac{k_{\mathrm{d}} t}{C_{\mathrm{e}}}\right)\right]
$$

Expressed as a fraction of the released API, defined as:

$$
F(t)=\frac{C(t)}{C_{\mathrm{e}}}
$$

equation (7) takes the form:

$$
F(t)=1-\exp \left(-\frac{k_{\mathrm{d}} t}{C_{\mathrm{e}}}\right)
$$

Of course, we expect the dynamics of the release of API to be governed by (9) as long as only a single desorption process is involved in the overall release (a single "desorption step"). If, however, more processes are relevant, equation (9) needs to be modified accordingly. If, for example, two processes (two desorption steps, or desorption step followed by diffusion etc.) are relevant to the API release from the formulation, one should use the following function to describe the time-evolution of $F$ :

$$
F(t)=\frac{C_{\mathrm{e}, 1}}{C_{\infty}}\left[1-\exp \left(-\frac{k_{\mathrm{d}, 1} t}{C_{\mathrm{e}, 1}}\right)\right]+\frac{C_{\mathrm{e}, 2}}{C_{\infty}}\left[1-\exp \left(-\frac{k_{\mathrm{d}, 2} t}{C_{\mathrm{e}, 2}}\right)\right]
$$

The two processes governing the overall release are characterized with two different rate constants, i.e. characteristic release times. Generalization to the $k$ processes case is obvious:

$$
F(t)=\sum_{i=1}^{k} \frac{C_{\mathrm{e}, i}}{C_{\infty}}\left[1-\exp \left(-\frac{k_{\mathrm{d}, i} t}{C_{\mathrm{e}, i}}\right)\right]=\frac{1}{C_{\infty}} \sum_{i=1}^{k} C_{\mathrm{e}, i}\left[1-\exp \left(-\frac{k_{\mathrm{d}, i} t}{C_{\mathrm{e}, i}}\right)\right]
$$

Description of the desorption process within Avrami's model is, on the other hand, based on the equation of the type:

$$
\frac{\mathrm{d} C}{\mathrm{~d} t}=k_{\mathrm{d}}^{n} t^{n-1}\left(C_{\mathrm{e}}-C\right)
$$

(where the parameter $n$ is known as Avrami's exponent) with the solution of the form:

$$
C(t)=C_{\mathrm{e}}\left[1-\exp \left(-\left(k_{\mathrm{d}} t\right)^{n}\right)\right]
$$

For the purpose of our study, we have relied on slightly different form of (12), adapted to the notation used in the works of Aguzii et al. (2013). The form of Avrami's differential equation that we have actually adopted in the present study is:

$$
\frac{\mathrm{d} C}{\mathrm{~d} t}=k_{\mathrm{d}}^{n} t^{n-1} \frac{\theta}{C_{\mathrm{e}}^{n-1}}
$$

with $\theta$ defined by (5). The operative solution of (14) that we have actually used for fitting of our experimental data is therefore:

$$
C(t)=C_{\mathrm{e}}\left[1-\exp \left(-\left(\frac{k_{\mathrm{d}} t}{C_{\mathrm{e}}}\right)^{n}\right)\right]
$$


Table 3. Physical properties of the prepared tablets $(n=10)$

\begin{tabular}{lccc}
\hline \hline $\begin{array}{l}\text { Physical properties } \\
\text { of tablets }\end{array}$ & Sample 1 & Sample 2 & Sample 3 \\
\hline $\begin{array}{l}\text { Diameter (mm) } \\
\text { mean } \pm \text { SD }\end{array}$ & $7.00 \pm 0.45$ & $6.99 \pm 0.51$ & $6.98 \pm 0.55$ \\
$\begin{array}{l}\text { Thickness (mm) } \\
\text { mean } \pm \text { SD }\end{array}$ & $3.24 \pm 0.23$ & $3.29 \pm 0.30$ & $3.24 \pm 0.57$ \\
$\begin{array}{l}\text { Hardness (kP) } \\
\pm \text { SD } \\
\begin{array}{l}\text { Porosity (\%) } \\
\text { mean } \pm \text { SD } \\
\text { Tensile strength mean } \\
\pm \text { SD }\end{array}\end{array}$ & $12.01 \pm 0.35$ & $14.22 \pm 0.47$ & $16.65 \pm 0.47$ \\
\hline
\end{tabular}

\section{Results and discussion}

\section{Characterization of final blends}

The flow properties of pharmaceutical powders and granules are usually characterized with multiple test methods in order to get adequate aspects of product flow. The results from characterization of the final blends (Table 2) indicated that the prepared samples have fair flow properties. Concerning the porosity of the final blends, sample 2 and 3 have a higher porosity compared to sample 1 .

\section{Tablet characteristics}

All tablets were smooth and elegant in appearance. Tablet weight variations for the samples in this study were found to be less than $1 \%$. Other physical parameters such as diameter, thickness and hardness of the tablets were found to be satisfactory (Table 3).

An important parameter in solid dosage form processing that requires precise detection and control is the hardness and calculated tensile strength of a compressed tablet. Hardness testing is an important parameter having in mind that it provides a quantitative estimate of the internal bonding strength of the powder compact, which is what gives the tablet sufficient mechanical strength to maintain its internal structure and geometry under applied external forces. Variations in tablet hardness are hence known to correlate with differences in dissolution or mechanical response.

It is also known that tablet porosity and pore structure are important characteristics of tablets, since they influence relevant properties such as mechanical strength and/or the intrusion of water, thus affecting tablet disintegration and drug release rate. The relationship between bulk porosity and tensile strength was notified and an exponential relation between these two parameters was observed (Nordström et al., 2013). As expected, our results showed that the tensile strength increased with decreasing total tablet porosity. Generally, increasing tablet hardness level significantly $(\mathrm{p}<0.05)$ decreases the porosity percentages.

Table 2. Characteristics of the final blends $(n=6)$

\begin{tabular}{lccc}
\hline Measured properties & Sample 1 & Sample 2 & Sample 3 \\
\hline $\begin{array}{l}\text { Bulk density } \\
(\mathrm{g} / \mathrm{mL}) \pm \mathrm{SD}\end{array}$ & $0.278 \pm 0.22$ & $0.300 \pm 0.05$ & $0.304 \pm 0.15$ \\
$\begin{array}{l}\text { Tapped density } \\
(\mathrm{g} / \mathrm{mL}) \pm \mathrm{SD}\end{array}$ & $0.331 \pm 0.2$ & $0.389 \pm 0.05$ & $0.389 \pm 0.12$ \\
$\begin{array}{l}\text { Carr index } \\
(\%) \pm \mathrm{SD}\end{array}$ & $16 \pm 0.5$ & $23 \pm 0.25$ & $22 \pm 0.89$ \\
$\begin{array}{l}\text { Hausner's ratio } \\
\pm \mathrm{SD}\end{array}$ & $1.19 \pm 0.91$ & $1.30 \pm 0.46$ & $1.28 \pm 1.11$ \\
$\begin{array}{l}\text { Angle of repose } \\
\left({ }^{\circ} \pm \mathrm{SD}\right.\end{array}$ & $36 \pm 1.12$ & $46.00 \pm 0.28$ & $43.50 \pm 0.89$ \\
$\begin{array}{l}\text { Porosity } \\
(\%) \pm \mathrm{SD}\end{array}$ & $60.62 \pm 1.25$ & $78.34 \pm 1.05$ & $78.08 \pm 1.02$ \\
\hline
\end{tabular}




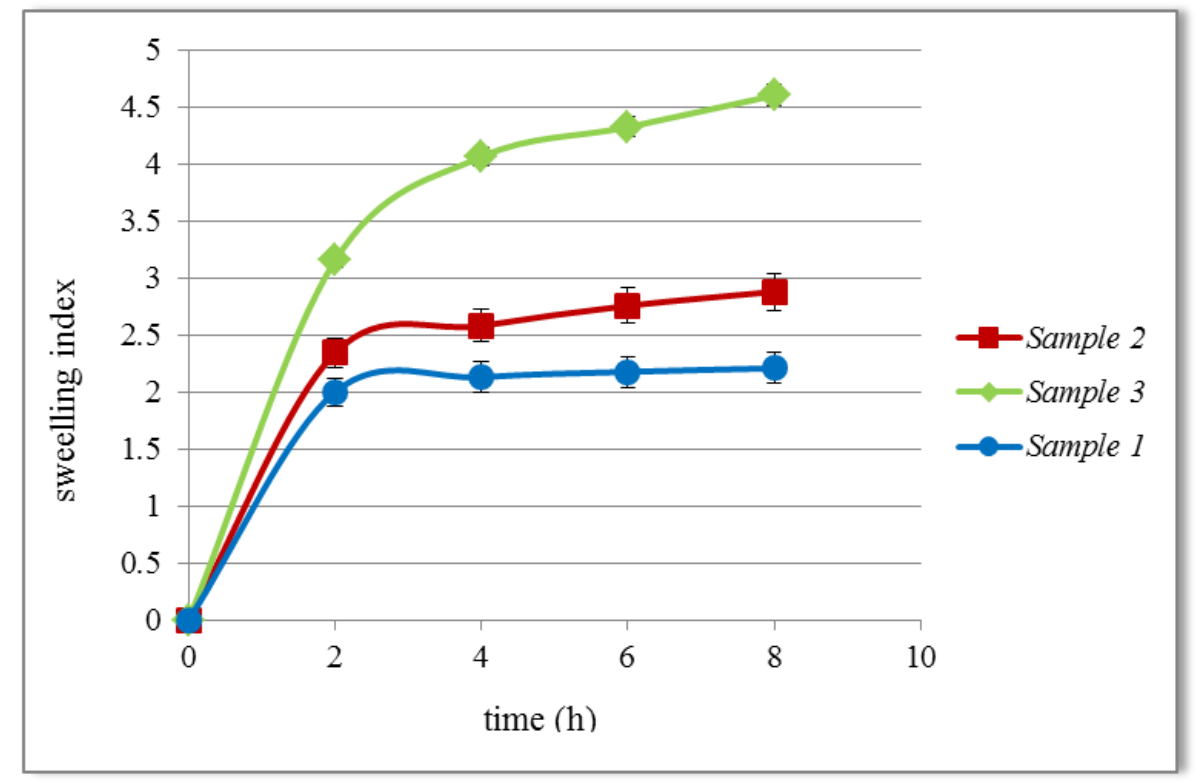

Fig. 1. Swelling index from the prepared tablets (mean $\pm \mathrm{SD}, n=6$ )

Also, tablet porosity is not just a predictor of dissolution (API release) and solvent ingress. With the growing importance of $\mathrm{QbD}$, porosity is also an important CQA for both disintegration and bioavailability properties (Samy et al., 2015) and therefore these parameters are vital to provide data to allow the prediction of API and excipients behavior in designed formulations and their influence on quality and efficacy.

Furthermore, the two most important consequences of significant polymer swelling in controlled release matrix systems are the length of the diffusion pathways and the mobility of the macromolecules (Siepmann and Siepmann, 2008). Water penetration via pores and/or through continuous polymeric networks, as well as swelling of the system and creation of water-filled pores are important phenomena for release of water soluble drugs.

The swelling index results and in vitro drug release from prepared tablet formulations are given in Figs. 1 and 2 , respectively.

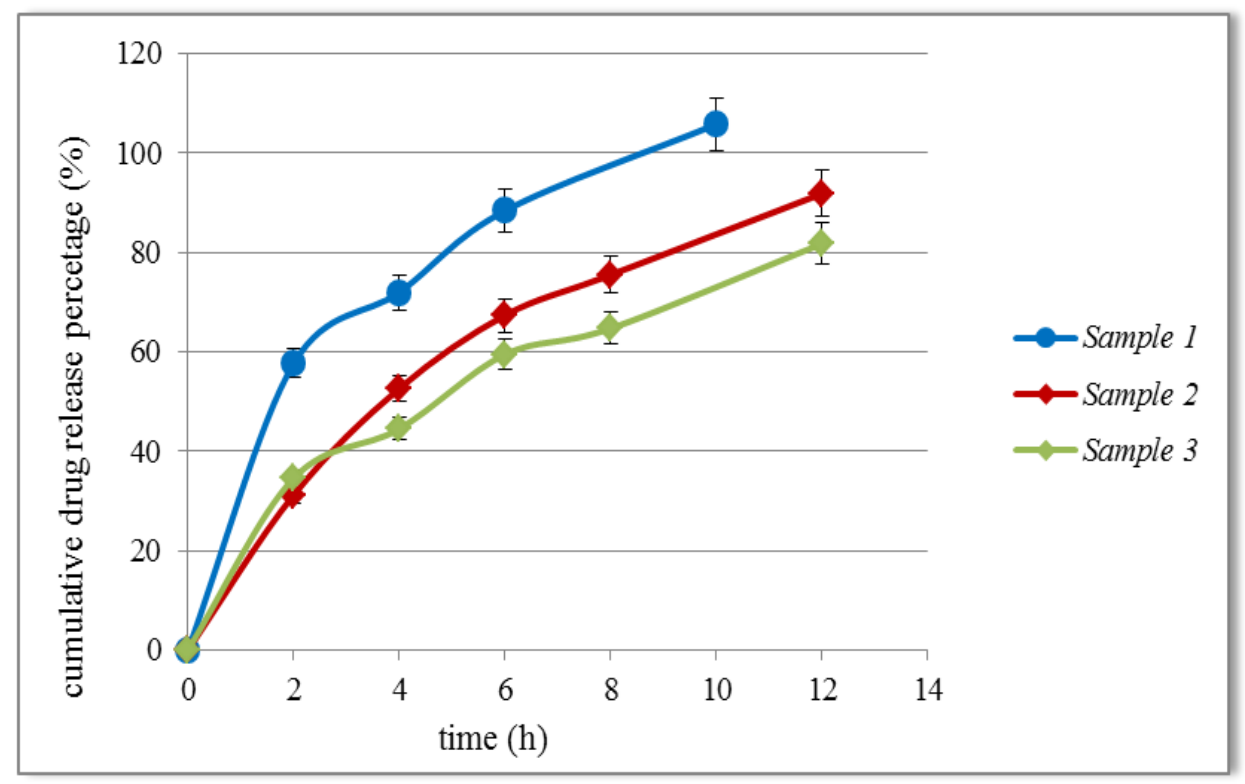

Fig. 2. In vitro drug release profiles from prepared tablet formulations (mean $\pm \mathrm{SD}, n=6$ ) 


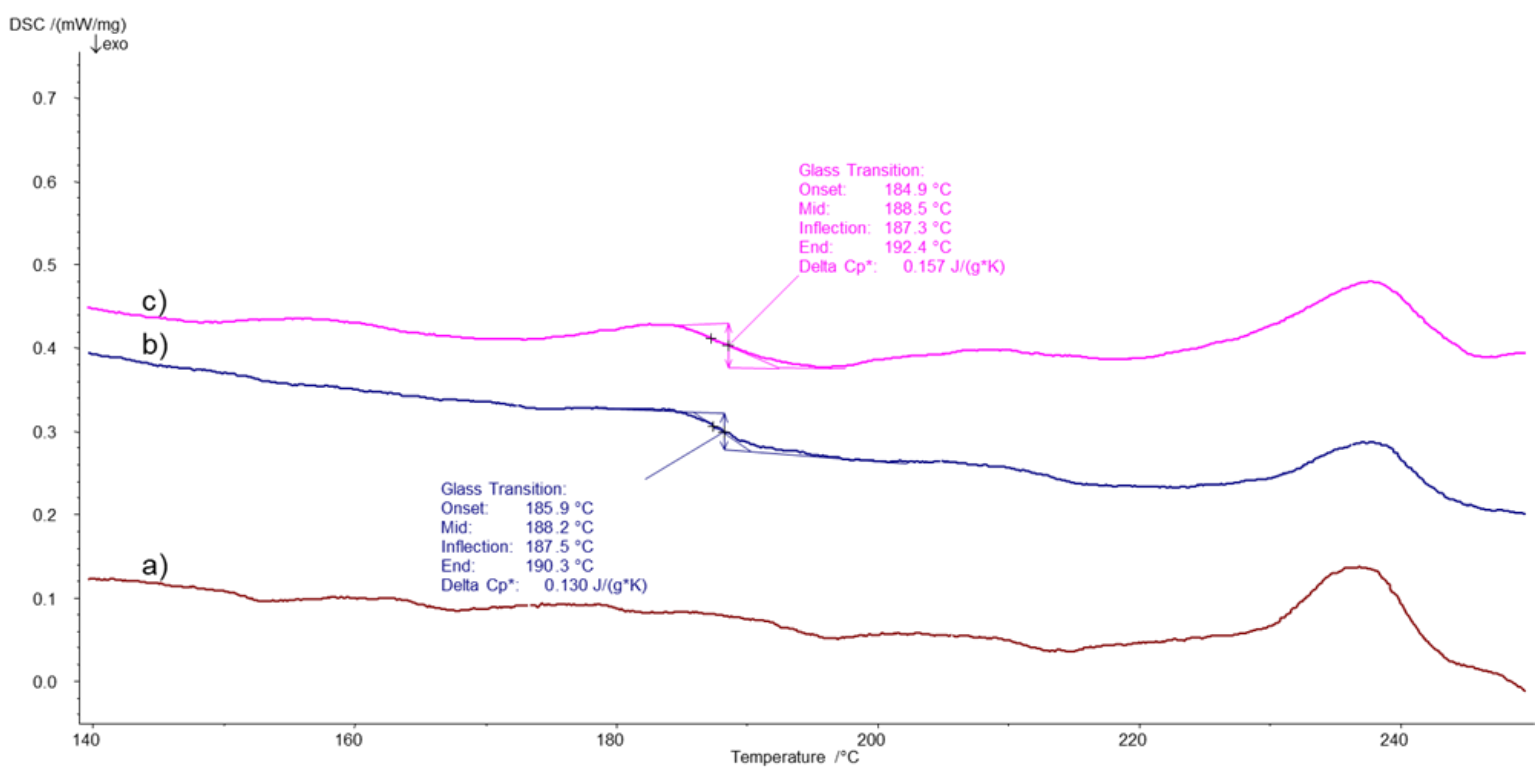

Fig. 3. DSC termorgams of mixtures prepared for tableting: a) mix of API, Methocel K100M, Avicel PH 112 and Kollidon K90 (intra-granularly) and Methocel K15M (extra-granularly), b) mix of API, Methocel K100M, Avicel PH 112 and Kollidon K90 (intra-granularly) and Methocel K4M (extra-granularly) and c) mix of API, Methocel K100M, Avicel PH 112 and Kollidon K90 (intra-granularly)

The samples 1, 2 and 3 showed large differences in the index of swelling and the same difference was not observed in the release profile of API, respectively. As it can be seen from Figs. 1 and 2, sample 1 containing only Methocel K100 (intra-granularly) has the lowest index of swelling and the faster release of API compared to samples 2 and 3. The previous work and results of our group (Petrovska Jovanovska et al., 2016) suggested that when Methocel as a polymer is added intra-granularly in the process of wet granulation, cross-linking of the polymer chains occurs. This physical modification results in lower swelling index, lower \% of water uptake and faster drug release rate. This phenomenon in the polymer structure was also confirmed using DSC, where in the DSC curve of the wet granulated Methocel, there was no the glass transition temperature $(T \mathrm{~g})$, compared to the untreated Methocel which $\mathrm{Tg}$ was observed at $\sim 189{ }^{\circ} \mathrm{C}$ (Sakellariou et al., 1985).

Furthermore, sample 2 containing Methocel K4M extra-granularly has a lower index of swelling and faster release of API compared to formulation sample 3. As it can be seen from Table 1 , sample 1 contains only Methocel K100M intra-granularly, and on the other hand, in sample 2 and sample 3 additional diffusion controlling polymers (from the same group but with different viscosity) were used as extra-granular excipients (Methocel K4M and Methocel K15M, for samples 2 and 3 , respectively). When Methocel $\mathrm{K} 4 \mathrm{M}$ and Methocel K15M (sample 2 and sample 3) are added extragranularly, they are considered not to undergo a change as a result of the applied technological process and have an advanced effect on the release of API in comparison to sample 1. Obtained results support previous studies indicating that the lower viscosity Methocel types (in our case Methocel K4M, $18802 \mathrm{cP}$ ) allows faster penetration of water into the matrix (Rassing, 1986) and they have a smaller index of swelling, that is, they create a weaker gel casing that is a weaker barrier to the release of API (Alderman, 1984). Incorporation of Methocel K15M (polymer with the higher viscosity grade, $126885 \mathrm{cP}$ ) in sample 3 was found to be more suitable to control the drug release from the designed system probably due to the slow drug diffusion from the swelled polymer gel layer which is also more resistant to erosion process (Daly et al, 1984).

Obtained results from in vitro release studies and the effect of polymers on drug release behavior were additionally confirmed by the DSC thermograms of the three mixtures prepared for tableting without the lubricant: a) mix of API, Methocel K100M, Avicel PH 112 and Kollidon K90 (intragranularly); b) mix of API, Methocel K100M, Avicel PH 112 and Kollidon K90 (intragranularly) and Methocel K4M (extragranularly) and c) mix of API, Methocel K100M, Avicel PH 112 and Kollidon K90 (intragranularly) and Methocel K15M (extragranularly) (Fig. 3). Namely, in the mixtures b and c (corresponding to samples 2 and 3), in which the additional polymer was added extragranularly (Methocel $\mathrm{K} 4 \mathrm{M}$ in mixture $\mathrm{b}$ and Methocel $\mathrm{K} 15 \mathrm{M}$ in mixture c), the $\operatorname{Tg}\left(\sim 157-180{ }^{\circ} \mathrm{C}\right)$ of the polymer is considered, which is probably due to the unchanged polymer chains, indicating that they retain their nature, and therefore their properties 
to affect the release properties of API.

In order to understand the release mechanism, the drug release data were fitted to different empirical equations. Values of estimated parameters are given in Table 4. By comparing the values of the correlation coefficient $(r)$ of different kinetic models, it can be clearly seen that release data showed best fitting to the heuristic model proposed by Korsmeyer-Peppas. Low values for $n$ (less than 0.5) are indicative for porous matrix structure, where Fickian diffusion is the main mechanism controlling the release rate of the API.

Other studies have shown that the drug release from Methocel matrices occurs as a consequence of a number of key processes: polymer wetting, hydration and swelling, gel layer formation, drug dissolution and diffusion through the gel layer. An additional factor is the dissolution and erosion of the polymer at the edge of the gel layer, a process which both reduces the size of the matrix and releases undissolved drug particles. In reality, the underlying mechanism of drug release from Methocel matrices is more complex because it involves many dynamic processes resulting in the moving boundaries known as the swelling, diffusion and erosion fronts (Narasimhan, 2001), which was also confirmed in our present work (Table 4).

We have fitted our experimental data for the studied formulations with various model functions of the general form (11), considering different number of processes involved in API release kinetics (actually, for $k=1$ and 2 in the present case; due to the number of available experimental data points, fitting with $k=3$ was not possible). Least-squares fitting have been performed rather carefully, monitoring the statistical significance of the fitting parameters for each particular case.

In all studied cases, it has been found that a model involving just a single process is sufficient to describe the observed dissolution kinetics, within the approach analogous to that of Aguzzi et al. (2013). This, however, as will be seen further, does not exclude the inherent complexities of the desorption processes taking place in the studied systems (vide infra). Fits with model function of the form (7) are shown in Fig. 4. Table 5 on the other hand, compiles the model function parameters obtained by the least-squares fits, along with some statistical parameters characterizing the goodness-of-fit. Only in the case of sample 3, it was possible to achieve a reasonable fit that would lead to physically reasonable model parameters, with the function of the form (10). However, the desorption constant for the faster process was found to be three to four orders of magnitude larger than the one obtained assuming a single - process model. Therefore, aside from mathematical appropriateness of a two process model in the case of this formulation, its physical justification would seem too speculative to consider it further. It is, however, worth mentioning at this point that the experimental data for sample 3 could not be fitted to the Avrami's model function of the form (15) allowing all three fitting parameters to vary, in contrast to all other cases considered in the present study.

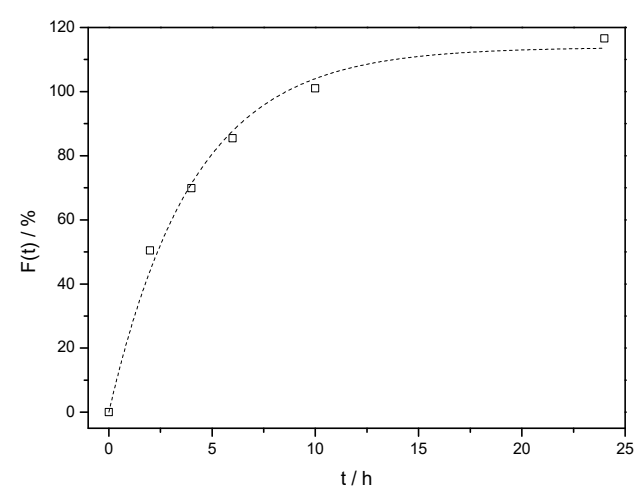

a)

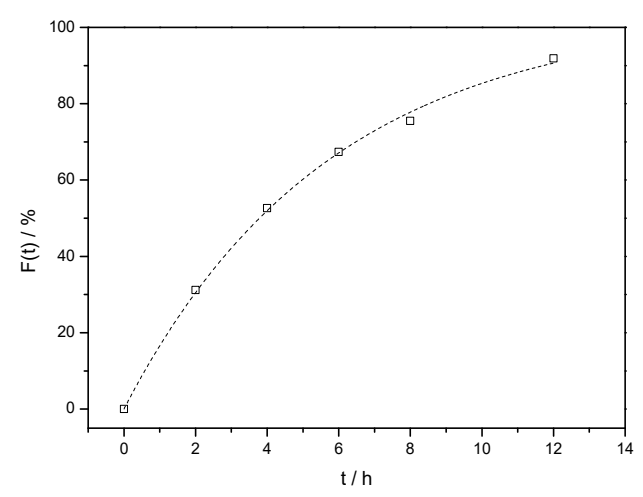

b)

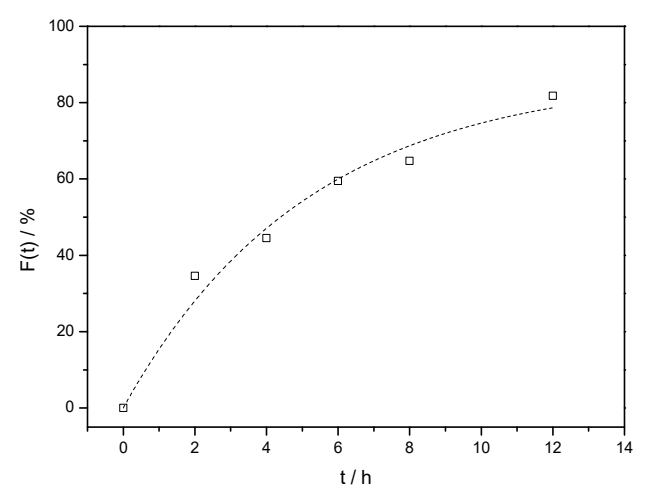

c)

Fig. 4. Experimental data for $F(t)$ for the studied series of formulations together with the fits to model function of the form (7): a) sample 1, b) sample 2 and c) sample 3

Substantial improvement of the fits has been, however, obtained by employing the modified Avrami's approach. Experimental data together with the fits with modified Avrami's model function of the form (15) are 
Table 4. In vitro release kinetic values of API from different tablet formulations

\begin{tabular}{lccccccccc}
\hline \hline & \multicolumn{2}{c}{ Higuchi } & \multicolumn{2}{c}{ First order } & \multicolumn{3}{c}{ Hixon Crowel } & \multicolumn{3}{c}{ Korsmeyer-Peppas } \\
& $k\left(h^{1 / 2}\right)$ & $r$ & $k\left(h^{-1}\right)$ & $r$ & $k\left(h^{1 / 2}\right)$ & $R$ & $K\left(h^{-1}\right)$ & $n$ & $r$ \\
\hline Sample 1 & 26.441 & 0.9958 & 0.186 & 0.9990 & 0.051 & 0.996 & 23.907 & 0.550 & 0.9971 \\
Sample 2 & 23.436 & 0.9981 & 0.148 & 0.9870 & 0.041 & 0.974 & 23.484 & 0.498 & 0.9981 \\
Sample 3 & 35.293 & 0.9923 & 0.378 & 0.9905 & 0.097 & 0.986 & 43.306 & 0.388 & 0.9993 \\
\hline
\end{tabular}

shown in Fig. 5. In Table 6, the model function parameters obtained by the least-squares fits, along with some statistical parameters characterizing the goodnessof-fit are compiled.

Table 5. Parameters obtained by the least-squares fits of the experimental data for the studied formulations with model function of the form (7), along with some statistical parameters characterizing the goodness-of-fit (see text for more details)

\begin{tabular}{ccccc}
\hline \hline Sample & $k_{d} / h^{-1}$ & $C_{e} / \%$ & $R^{2}$ & $R_{\text {adjusted }}^{2}$ \\
\hline 1 & 27.96 & 113.82 & 0.99244 & 0.99055 \\
2 & 18.06 & 103.34 & 0.99859 & 0.99824 \\
3 & 16.94 & 87.111 & 0.98147 & 0.97684 \\
\hline
\end{tabular}

In the case of both samples 1 and 2 , it can be seen from Table 6 that a fractional order $n$ has been obtained to achieve the best nonlinear least-squares fits of the experimental data within the framework of Avrami's model. Such observation strongly suggests that the actual mechanism of desorption is inherently complex, in the sense that either more than one reaction pathways are possible during the desorption process, or even that a change of mechanism could take place during the desorption process. Having in mind the nature of formulations considered in the present study, the previous implications are quite logical. Of course, phenomenological parameters derived by analysis of the kinetics of the desorption process can not exactly discriminate the particular mechanism being responsible for the actual observations. For that purpose, more exact analyses of the encountered phenomena are required, e.g. by contemporary molecular modeling methodologies.

\section{Conclusion}

A prolonged release matrix tablets containing water soluble model opioid drug were developed using Methocel K100M as intra-granular polymer along with Methocel K4M or Methocel K15M as extra-granular polymers. The type of Methocel used, as critical material attribute (CMA), was found to significantly affect the tablet properties especially the release behavior, as the critical quality attribute (CQA) of the final drug product. It is believed that the viscosity of different Methocel types influence the partial wetting, hydration and swelling, and subsequent gel layer formation of the swollen matrix system, thus extending the dissolution behavior of opioid tablets. Obtained results indicated that it may be possible to control the release rate of water soluble drugs by using different grades of Methocel and modifying their total concentrations, as well as by applying proper technological solutions for matrix tablet manufacturing process.

\section{Acknowledgment}

This work was supported by pharmaceutical company ALKALOID AD, Skopje, Macedonia and Horizon 2020. VI-SEEM, Project reference: 675121, VRE (Virtual research Environment) foe regional Interdisciplinary communities in Southeast Europe and eastern Mediterranean), 2015-2018.

\section{References}

Aguzzi, C., Viseras, C., Cerezo, P., Salcedo, I., Sánchez-Espejo, R., Valenzuela, C., 2013. Release kinetics of 5aminosalicylic acid from halloysite. Colloids Surf. B. 105, 75-80. Available at: https://doi.org/10.1016/j.colsurfb.2012.12.041.

Alderman, D.A., 1984. A review of cellulose ethers in hydrophilic matrices for oral controlled-release dosage forms. Int. J. Pharm and Tech. Prod. Man. 5(3), 1-9. Available at: https://doi.org/10.3109/03639049709148697.

Charoo, N.A., Shamsher, A.A., Zidan, A.S., Rahman, Z., 2012. Quality by design approach for formulation development: a case study of dispersible tablets. Int. J. Pharm. 423(2), 167178. Available at: https://doi.org/10.1016/j.ijpharm.2011.12.024.

Daly, P.B., Davis, S.S., Kennerley, J.W., 1984. The effect of anionic surfactants on the release of chlorpheniramine from a polymer matrix tablet. Int. J. Pharm. 18, 201-205. Available at: https://doi.org/10.1016/0378-5173(84)901200.

Franc, A., Kurhajec, S., Pavlokova, S., Sabadkova, D., Muselik, J., 2017. Influence of concentration and type of microcrystalline cellulose on the physical properties of tablets containing Cornelian cherry fruits. Acta Pharm. 67, 187-202. Available at: https://doi.org/10.1515/acph-20170019 . 
Narasimhan, B., 2001. Mathematical models describing polymer dissolution: consequences for drug delivery. Adv. Drug Deliv. Rev. 48, 195-210. Available at: https://doi.org/10.1016/S0169-409X(01)00117-X.

Nokhodchi, A., Raja, S., Patel, P., Asare-Addo, K., 2012. The role of oral controlled release matrix tablets in drug delivery systems. BioImpacts BI 2(4), 175-187. Available at: https://doi.org/10.5681/bi.2012.027.

Nordström, J., Persson, A., Lazorova, L., Frenning, G., Alderborn, G., 2013. The degree of compression of spherical granular solids controls the evolution of microstructure and bond probability during compaction. Int. J. Pharm. 442(1-2), 3-12. Available at: https://dx.doi.org/10.1016/j.ijpharm.2012.08.011.

Petrovska Jovanovska, V., Chacorovska, M., Stojanovska, M., Petruševski, Gj., Ugarkovic, S., Glavas Dodov, M., 2016. Porosity as critical material attribute (CMA) in modified release matrix systems. Arhch. Farm. (Special issue), 255256.

Rassing, J., 1986. Diffusion in hydroxypropylmethylcellulose an ultrasound method. J. Contol. Release, 3, 131-136. Available at: https://doi.org/10.1016/01683659(86)90073-8.

Sakellariou, P., Rowe, R. C., White, E.F.T., 1985. The thermomechanical properties and glass transition temperatures of some cellulose derivatives used in film coating. Int. J. Pharm. 27(2-3), 267-277. Available at: https://doi.org/10.1016/0378-5173(85)90075-4.

Samy, Y., Goodwin, D.J., Anderson, A., Sibik, J., Ian Wilson, D., Gladdedn, L., Zeitler, A., 2015. The disintegration process in microcrystalline cellulose based tablets, Part 1: Influence of temperature, porosity and superdisintegrants. J. Pharma. Sc., 104(10), 3440-3450. Available at: https://doi.org/10.1002/jps.24544.

Saurí, J., Millán, D., Suñé-Negre, J.M., Colom, H., Ticó, J.R., Miñarro, M., Pérez-Lozano, P., García Montoya, E., 2014. Quality by Design approach to understand the physicochemical phenomena involved in controlled release of captopril SR matrix tablets. Int. J. Pharm. 477(1-2), 431-441. Available at: https://doi.org/10.1016/j.ijpharm.2014.10.050.

Siepmann, J., Siepmann, F., 2008. Mathematical modeling of drug delivery. Int. J. Pharm. 364, 328-343. Available at: https://doi.org/10.1016/j.ijpharm.2008.09.004.

Smith, H., 2012. A comprehensive review of rapid-onset opioids for breakthrough pain. CNS Drugs 26(6), 509535. Available at: https://doi.org/10.2165/11630580000000000-00000.

Yu, L.X., Amidon, G., Khan, M.A., Hoag, S.W., Polli, J., Raju, G.K., Woodcock, J., 2014. Understanding pharmaceutical quality by design. The AAPS Journal 16(4), 771-783. Available at: https://doi.org/10.1208/s12248-014-9598-3.

\title{
Физичко-хемиска карактеризација и in vitro евалуација на матрикс таблети со модифицирано ослободување: Улога на вискозноста на различни видови на хифроксипропил метилцелулози
}

\author{
Весна Петровска Јовановска ${ }^{1}$, Љупчо Пејов ${ }^{2}$, Александра Петровска ${ }^{1}$, \\ Соња Угарковиќ ${ }^{1}$, Маја Симоноска Црцаревска ${ }^{3}$, Марина Галева $^{3}$, \\ Марија Главаш Додов ${ }^{3}$ \\ ${ }^{1}$ Институт за истражување и развој, Алкалоид АД-Скопје, \\ бул. Александар Македонски 12, 1000 Скопје, Македонија \\ ${ }^{2}$ Институт за Хемија, Природно-математички факултет, \\ Универзитет „Св. Кирил и Методиј“, ПОФ 162, 1001 Скопје, Македонија \\ ${ }^{3}$ Институт по фармацевтска технологија, \\ Центар за Фармацевтска нанотехнологија, Фармацевтски факултет, \\ Универзитет „Св.Кирил и Методиј“, Мајка Тереза 47, 1000, Скопје, Македонија
}

Клучни зборови: матрикс таблети, водорастворлива опоидна супстанција, пролонгирано ослободување, НРМС (Methocel)

Целта на овој труд беше да се формулираат матрикс таблети со продолжено ослободување пто содржат водорастворлива опоидна активна супстанција (АПИ) со примена на различни видови на хидроксипропилметил 
целулози (Methocel), како полимери што го контролираат ослободувањето на активната супстанција. Меthocel K100M беше инкорпориран како интрагрануларен полимер (примерок 1) заедно со Methocel K4M (примерок 2) или Methocel K15M (примерок 3), како екстрагрануларни полимери. Финалните мешавини беа подготвени со примена на методот на влажна гранулација. Финалните мешавини, како и подготвените таблети беа соодветно карактеризирани.

Резултатите укажаа дека полимерите применети ектрагрануларно значајно влијаат врз особините на таблетите. Со инкорпорирање на Methocel ектрагрануларно (примероци 2 и 3), цврстината на таблетите беше зголемена додека порозноста на таблетите беше намалена. Примерокот 1 (кој содржи само Methocel K100М интрагрануларно) имаше низок индекс на бабрење и најбрзо ја ослободува АПИ што најверојатно се должи на вкрстеното поврзување на полимерните ланци за време на процесот на влажна гранулација. Видот на Меthocel инкорпориран ектрагранулатно (со различен вискозитет) значително имаше влијание врз степенот на бабрење на матриксот, како и врз брзината на ослободувањето на АПИ. Примерокот 2 (co Methocel K4M екстрагрануларно) имаше понисок индекс на бабрење како и побрзо ослободување на АПИ во споредба со примерок 3. Земајќи го во предвид механизмот на ослободување, ослободувањето најдобро можеше да се објасни со примена на моделот преложен од Korsmeyer-Peppas. Беа применети и два дополнителни математички модели со цел истите директно да бидат применети за нашите експериментални податоци. 
